\title{
Nursing students' errors in clinical learning. Qualitative outcomes in Mixed Methods Research
}

\author{
Erros dos estudantes de enfermagem em aprendizagem clínica. Resultados qualitativos em investigação de métodos mistos
}

Errores de los estudiantes de enfermería en aprendizaje clínico. Resultados cualitativos en investigación de métodos mixtos

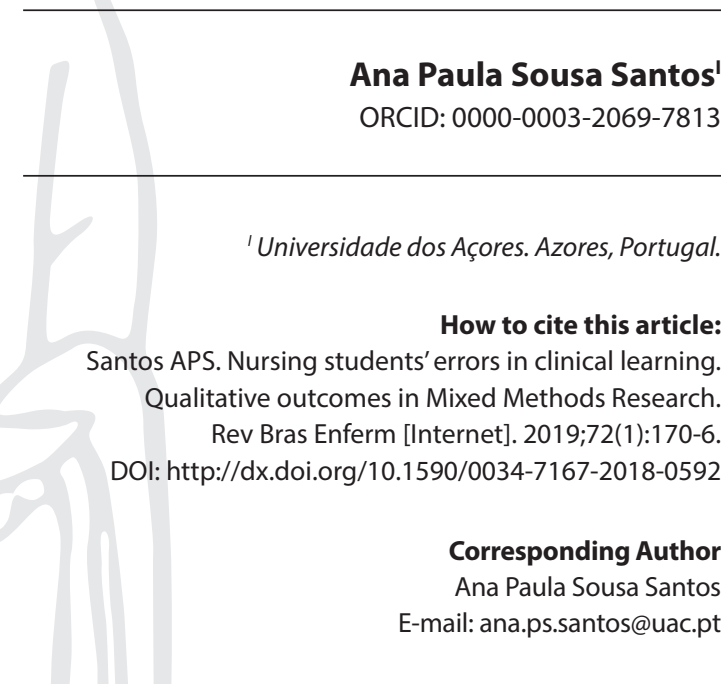

Submission: 07-20-2018 Approval: 10-17-2018

\section{ABSTRACT}

Objective: to analyze factors associated with nursing students' errors during clinical learning, and their perceptions regarding these events and the opportunity for learning and development provided by them. Method: Convergent Mixed Method design according Creswell and Clark. Qualitative dimension included face to face and internet interviews. Data analysis followed Miles and Huberman method. Results: Nursing student's errors were revealed according to their perceptions. They occurred in all phases of the nursing process and in transversal skills. Errors were acknowledged as learning and developmental opportunities. Final considerations: Students acknowledged their errors and ascribe to themselves reasons and what could have prevented what happened. Mixed Method was a very adequate design to study phenomena. Qualitative dimension was essential to reveal and achieve the objectives. Suggestions founded on the findings are presented.

Descriptors: Nursing Research; Education, Nursing; Students, Nursing; Medical, Errors; Qualitative Research.

\section{RESUMO}

Objetivo: analisar fatores associados aos erros dos estudantes de enfermagem durante a aprendizagem clínica e as suas perceções destes eventos constituírem oportunidade de aprendizagem e de desenvolvimento. Método: Investigação com desenho de Métodos Mistos de acordocom Creswell e Clark. A dimensão qualitativa incluiu entrevistas presenciais e pela internet. A análise de dados seguiu o método de Miles e Huberman. Resultados: Os erros dos estudantes foram revelados Segundo as suas perceções em todas as fases do processo de enfermagem e nas competências transversais. Os erros foram reconhecidos como oportunidades de aprendizagem e de desenvolvimento. Considerações Finais: Os estudantes reconheceram o seus erros e atribuíram a sim mesmos as razões e o que teria prevenido a sua ocorrência. O Método Misto foi um desenho adequado para estudar o fenómeno. A dimensão qualitativa foi essencial para revelar e alcançar o objetivo. São apresentadas sugestões alicerçadas nos resultados.

Descritores: Pesquisa em Enfermagem; Educação em Enfermagem; Estudantes de Enfermagem; Erros Médicos; Pesquisa Qualitativa.

\section{RESUMEN}

Objetivo: analizar los factores asociados a los errores de los estudiantes de enfermería durante el aprendizaje clínico y sus percepciones con respecto a estos eventos y la oportunidad de aprendizaje y desarrollo que proporcionan. Método: Diseño de método mixto convergente según Creswell y Clark. La dimensión cualitativa incluyó entrevistas presenciales y por internet. El análisis de los datos siguió el método de Miles y Huberman. Resultados: Los errores de los estudiantes de enfermería fueron revelados de acuerdo a sus percepciones. Ocurrieron en todas las fases del proceso de enfermería y en habilidades transversales. Los errores fueron reconocidos como oportunidades de aprendizaje y desarrollo. Consideraciones finales: los estudiantes reconocieron sus errores y se atribuyeron las razones y lo que pudría haber evitado lo que sucedió. El método mixto fue un diseño muy adecuado para estudiar los fenómenos. La dimensión cualitativa fue esencial para revelar y lograr los objetivos. Se presentan sugerencias fundamentadas en los hallazgos.

Descriptores: Investigación en Enfermería; Educación en Enfermería; Estudiantes de Enfermería; Errores Médicos; Investigación Cualitativa. 


\section{INTRODUCTION}

To err is human. Although this is a common phrase, when it comes to health professional in general and to nursing in particular, not only errors can be dangerous but they are not well accepted nor comfortable. Even so, going through professional life without an error might be exception and not rule. There should not be complacency and to face the issue with the dignity that being a nurse demands, errors must be acknowledged, not hidden, as a way of professional and personal development in order to assure a safe and ethic professional practice ${ }^{(1-3)}$.

In nursing, where contact and responsibility for human wellbeing and life are constant, the occurrence of errors is poorly considered and often attributed to malpractice. If this is so in professional practice, what will it be like when the person who commits an error is still a student, having to account for their benefit to clients, teachers, nurses and colleagues? Of his performance depends his academic success, translated into a final classification and the achievement of the goal of finishing the program and being a nurse. Health care errors, including nursing, are responsible for more deaths in the United States than any other cause, regardless of the context: hospital, community service, or client residence ${ }^{(4)}$. Medication errors are frequent in hospitals and there is more safety in airplanes than in hospitals, so health systems must establish safety rules as there are in aviation or in chemical industry in order to minimize errors and their effects. Although the situation is at an unacceptable level, with serious damages, only the tip of the iceberg is known; there is no taxonomy for classification of errors. These occurrences can be a way of constructive learning by replacing blame for prevention $^{(5-6)}$. As in all security systems, errors do not have genesis in a single cause but in multiple convergences. Referring specifically to hospitals, the whole system is large and complex and safety is in the interaction of personal, instrumental and procedural factors $^{(7)}$. They have important economic and social implications such as increased costs of health services due to more hospitalization days, additional treatment, absenteeism of the injured person, and lack of confidence in the health system and its professionals ${ }^{(8)}$.

This research aim was to analyze factors associated with errors committed by nursing students during clinical learning and their perceptions regarding these occurrences and learning and developmental opportunity from them.

\section{OBJECTIVE}

To analyze factors associated with nursing students' errors during clinical learning, and their perceptions regarding these events and the opportunity for learning and development provided by them.

\section{METHOD}

\section{Ethical aspects}

Authorization from Director of the School was obtained. Since there were no Committee of Ethics at the time, this Director had the competencies to analyze and authorize any research proposal. Belmont Report Ethics guidelines was the ethics foundation for all the study.

\section{Theoretical-methodological framework}

The research questions that guided the study were: 1) What is the perception of nursing students about what is an error in nursing care? 2) What errors occur in the clinical learning of nursing students? 3) What sociodemographic and scholar factors of nursing students are associated with the occurrence of errors in clinical learning? 4) What dispositional, self-perceiving, and developmental factors underlie students who err in clinical learning? 5) What are the nursing students' perceptions of their errors in clinical learning regarding circumstances that surround it? 6) To what extent do the students consider that the errors they committed contributed, hindered or impeded their learning and development?

The study followed a Mixed Methods Convergent Design proposed by Creswell and Clark (2011) $)^{(6)}$.

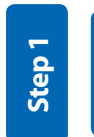

Design the Quantitative Strand Collect the Quantitative Data Collect the Quantitative Data

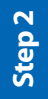

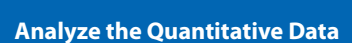
Analyze the Quantitative Data

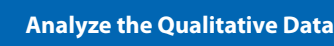

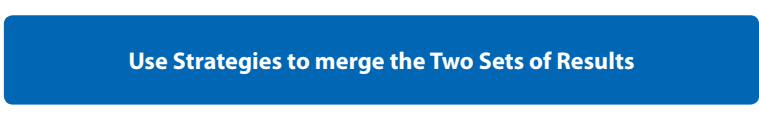
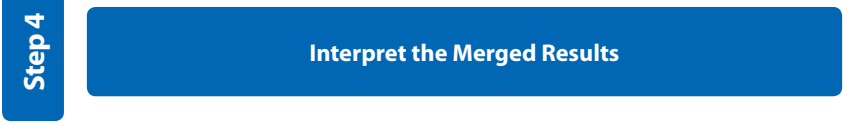

Source: Creswell \& Clark, $2011^{(9)}$

Figure 1 - Mixed Methods Convergent Design

\section{Study design}

As stated above, it was a mixed methods research (doctoral thesis). In this paper the focus is on qualitative outcomes.

\section{Methodological Procedures}

\section{Study setting}

The study was conducted in Escola Superior de Enfermagem de Ponta Delgada, Azores, Portugal. This organization was founded in 1958 and has provided graduated and post graduated nursing degrees. Regarding clinical teaching in which this study is focused they occurred in medical and surgical wards at the public city hospital. Staff nurses were clinical mentors guiding students in the real practice of nursing care. Faculty were pedagogical mentors who guided students in pedagogical and scientific parts of their learning process. 


\section{Data source - Study participants}

Participants were the students of $2^{\text {nd }}$ and $4^{\text {th }}$ year of Baccalaureate Nursing Program Data collecting started with quantitative methods and tools. A total of 86 students was enrolled in this step (54 belonging to $2^{\text {nd }}$ year and 32 to $4^{\text {th }}$ year). In the qualitative part, volunteers among all participants were asked. There were 41 nursing students: 24 from $2^{\text {nd }}$ year; 17 from $4^{\text {th }}$ year.

\section{Data collection and organization}

According to the method, Step 1 - Figure 1, designing and planning, occurred at same time.

Quantitative data collection occurred in the first day of clinical learning: sociodemographic data; locus of control; general efficacy self-perception; stress levels; moral development. The four scales were used again to collect data in the end of clinical learning. During 15 weeks - the time that clinical learning lasted - students answered a survey in which they presented perception of their nursing care and if committed errors. In case of errors occurrence, described what happened in a free style written document. Quantitative data was immediately updated to SPSS (Statistical Package for Social Sciences), version 17. Free report of errors was submitted to content analysis.

After clinical learning, in depth open interviews followed.

In this case, there was the assumption, since the interview is the deepening of experiences that could have been more or less difficult, that the student should not only be a rich case of information, that is, have lived experience about the phenomenon under study ${ }^{(9)}$, but be at ease and agree to talk about it.

The interviews in presence took place in a climate of relaxation, as true conversations that allowed obtaining indispensable information. It was also conducted online interviews, mediated by computer, namely through the program MSN Messenger ${ }^{\mathrm{TM}}$ and in written format, which is increasingly common ${ }^{(10)}$. By this way, although the non-visualization of the other person can be difficult, it has the advantage of providing time for reflection and disinhibition. Participants choose the mean by which they preferred the interview. Face to face interviews were recorded on magnetic audio tape to preserve everything that was said for later analysis. Recording interviews allow reliability because it preserves all conversations between interviewer and interviewee.

After each interview, as soon as possible, field notes was written. They included impressions of what happened, namely interviewer performance and participant responses and reactions. Field notes went on during transcription of face to face interviews, which took place as immediately as possible. In computer-mediated interviews, it was made edition of what was written since students often used typical forms of writing in online chat rooms, such as "Kem", "qdo" or "td" and expressions such as $(;)$ (smile) or $:$ (sadness). At the beginning of the interview it was noted participant's real name, identification code and start time. At the end it was recorded the time and placed an ID, which safeguarded confidentiality (eg 2-2, which means 2 nd year - interview 2 ) on the label of the magnetic tape or in the edited copy of the text, depending on the medium of the data collection. Benefits of face-to-face interviews included recognition of nonverbal expression; eyes contact and interaction. Benefits of online interviews were time to think; easy to edit data without transcription.

Data saturation was achieved; it was found similar information either among participants or in the same participant.

\section{Data analysis}

Analyzing data is to examine systematically a set of informative elements to delimit and discover relationships between them and the whole. The purpose is to know better the reality studied and to elaborate conceptual models that explain it. I's an intuitive, flexible process, oriented to assign meaning to raw data. This research approach to data analysis was modeled on Miles and Huberman (1994) ${ }^{(11)}$. It is a dialectical process, in a movement between the stages: data reduction; data display; conclusions: drawing/verifying.

Codification happened as follows. Since the elaboration of the initial problem and the respective literature review, before data collection, research dimensions were known: 1) errors committed by students during clinical learning, and 2) possibility of learning and development with that error. There were no previous categorization. For the organization of data, interviews were read several times in order to get an overview. Then it was marked by highlighting in color the text segments according to what was considered in the first (in red) or in the second (blue) dimension of the study. Then we assign a code according to what appeared in each dimension. Codes should be: valid (accurately reflect what is being investigated); mutually exclusive (distinct, without overlapping); exhaustive (all relevant data must fit into a code).

Categorization allows to conceptually classify units of analysis included in the same topic. A category encompasses a meaning or type of meanings, and may refer to a situation and context, activities and events, relationships between people, behaviors, opinions, feelings, perspectives, methods and strategies or processes. It occurs simultaneously with separation in units of analysis when, as in this study, the criterion is thematic, because when separating a unit by referring to a certain subject, immediately it can be included in the category that corresponds to it. Categorizing data involves judgments, deciding whether or not particular units of analysis can be included in a code and make decisions in this regard. The categories can be established by deduction, from a theoretical and conceptual framework designed for that purpose, that is, a priori or, as the data are examined, in an inductive process, a posteriori. In this study, dimensions were a priori but categories were established a posteriori; those that arose were provisional and, as codification progressed, were consolidated. This inductive process leads to a system of categories, product of analysis, and constitutes a map of meanings that reflects the complexity of human experience. It was obtained category, subcategory 1 , subcategory 2, and in some cases subcategories 3 and 4. This process applied as a single classification criterion and mutual exclusion was fulfilled.

Charts and figures were designed. They included dimensions and respective categories, which are representations or visual images of the relations between concepts and are important 
instruments of analysis to understand data and results. Matrices that accommodated different types of information were included. They consisted in presentation of charts and aspects specified in rows and columns ${ }^{(11)}$. Matrices in this study include dimension in its title. In the matrix itself, the leftmost column shows the category, followed by the columns of subcategories 1, 2 and 3, respectively. Next, always orienting from left to right, there is a wider column for the analysis units. The last column on the right served to locate/place the unit in the transcript of the interview, presented by "I" corresponding to "Interview" and "L" corresponding to "Line". For example, I3: L200-203 indicates that unit is in Interview 3, line 200 to 203.

Chart 1 - Analysis matrix example

\begin{tabular}{|c|c|c|c|l|c|}
\hline Category & Subcat. 1 & Subcat. 2 & Subcat. 3 & Unit of analysis & Place \\
\hline $\begin{array}{c}\text { Contributions } \\
\text { to error }\end{array}$ & $\begin{array}{l}\text { Student } \\
\text { himself/ } \\
\text { herslfelf }\end{array}$ & Fadigue & & $\begin{array}{l}\text { "With the last patient } \\
\text { with a vesical probe } \\
\text { that I had, I associated } \\
\text { with my exhaustion. } \\
\text { During my internship } \\
\text { I was all wrapped up } \\
\text { emotionally." }\end{array}$ & $\begin{array}{l}\text { E2-2: L62-64; } \\
97-98\end{array}$ \\
& & $\begin{array}{l}\text { "Above all it was } \\
\text { tiredness. I was not } \\
\text { able of more. [...] I } \\
\text { was really tired [...]." }\end{array}$ & 37-30-31; $66-77$ \\
\hline
\end{tabular}

In this study some strategies were followed, namely theoretical consolidation, that is, confrontation of the results obtained with the initial bibliographical revision, recourse to other concepts and theories by searching more general positions to integrate data, thus enabling its naturalistic generalization. To assure impartiality, qualitative data analyses occurred before statistical analysis. After categorization, it was given to each participant his/her matrix to validate. Fourteen did not, so there were $65.85 \%$ validations. There were validation of data analysis by two external experts (nursing and education) who were reviewers. To this, they analyzed aims of the research, guiding questions, interviews and codes.

\section{RESULTS}

Qualitative dimension of the research made possible to answer research questions 1 ), 2), 5), and 6).

Following guiding questions of this research, main results from qualitative dimension of the study are presented:

\section{What errors occur in the clinical learning of nursing students?}

Implementing phase of nursing care was the one with more errors, following medication errors, errors in needs identification, errors in transversal (soft) skills, errors in care planning, and, at las, errors in care evaluation.

In the implementing phase of nursing care, what was more evident for both year students was errors in "Implementation of the procedures according to the respective standard/norm", followed by "Rationale of the procedures in the execution of nursing care". In the first case, errors were in following procedures guidelines while in the second case it was focused on knowledge.

Medication errors happened most during preparation and were avoided by mentor interference when student was not able to identify by himself/herself. Errors related with pharmacology and other knowledge necessary to deal with medication by a nurse come immediately after. Surprisingly, these errors were most present in the $4^{\text {th }}$ year students than in the $2^{\text {nd }}$ year.

Errors in needs identification included "Identification of patient's needs through observation" appeared in the first place by $2^{\text {nd }}$ year students while in the $4^{\text {th }}$ year it was "Identification of the client's needs through clinical process". So, it suggests that junior student's needs to train and deep observational skills. In the last year, students fail to read, consult, or understood patient's information presented in papers and computers.

Only 2 nd year students reported transversal skills, being the most acknowledged "Performance independent of the mentor's guidance" and "Definition of strategies to overcome difficulties". So, these students fail because they needed mentor's guidance in some activities that it was supposed they be more autonomous or because they acted alone when they must be with tutor's. Also, when faced difficulties, they were not able to find strategies to overcome them.

Errors in care planning were more reported by $2^{\text {nd }}$ year students than by $4^{\text {th }}$ year. For both, "Establishment of priorities" were where the errors happened more.

At last, errors in care evaluation were more reported by $2^{\text {nd }}$ year students than by $4^{\text {th }}$ year students, being mainly "Elaboration of records with useful information useful to continuity of care", so it was on writing what was essential to nursing care that was the focus of this category errors.

The following chart presents categories and subcategories from the most to less prevalent, and there are examples of participants words.

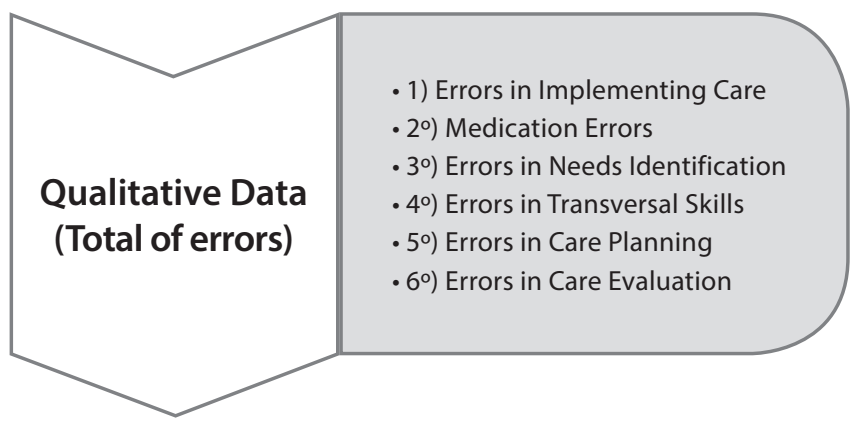

Figure 2 - Errors committed by nursing students during clinical learning - qualitative outcomes 
Chart 2 - Errors committed by nursing students during clinical learning

\begin{tabular}{|c|c|c|c|}
\hline Category & Subcategory 1 & Subcategory 2 & Examples - students' words/report \\
\hline \multirow[t]{3}{*}{$\begin{array}{l}\text { Errors in Implementing } \\
\text { Care }\end{array}$} & $\begin{array}{l}\text { Implementation of the } \\
\text { procedures according to } \\
\text { respective standard. }\end{array}$ & & $\begin{array}{l}{[\ldots] \text { make a dressing in the wrong way. }[\ldots] \text { disinfected the }} \\
\text { surgical wound in a reversed manner. (E2-15: L32; 35; 38-39) }\end{array}$ \\
\hline & $\begin{array}{l}\text { Rationale of the procedures in } \\
\text { nursing care. }\end{array}$ & & $\begin{array}{l}\text { There were moments of lack of knowledge either in pathologies } \\
\text { and medication. (E4-32: } \mathrm{L} 10-11 ; 53)\end{array}$ \\
\hline & $\begin{array}{l}\text { Carry out planned care in a timely } \\
\text { manner. }\end{array}$ & & $\begin{array}{l}\text { Patient was half shift without food, there was no need for that. } \\
\text { (E2-6: 158-159; 211-213) }\end{array}$ \\
\hline Medication Errors & & & $\begin{array}{l}\text { For example a patient had a medication at eight and at noon. A } \\
\text { certain dose at eight and a certain dose at twelve and I switched } \\
\text { doses. [...] The one at noon I gave at eight and the one at eight I } \\
\text { gave at twelve. [...]. (E2-6: L14-16: 18-19; 27-28) } \\
\text { I did not verify that I took a bottle of bicarbonate. I know the } \\
\text { intention was to get distilled water. (E4-9: L4-6) }\end{array}$ \\
\hline \multirow[t]{2}{*}{$\begin{array}{l}\text { Error in Needs } \\
\text { identification }\end{array}$} & $\begin{array}{l}\text { Identification of the patient's } \\
\text { needs through the clinical } \\
\text { process. }\end{array}$ & & $\begin{array}{l}\text { So I went to check if that patient really had prescribed } \\
\text { acetaminophen. She had but it was in SOS. I did not check the } \\
\text { last administration. (E4-42: L50-55) }\end{array}$ \\
\hline & $\begin{array}{l}\text { Identification of patient's needs } \\
\text { through observation. }\end{array}$ & & $\begin{array}{l}\text { I was still not very accustomed to the numbering of the bed, and } \\
\text { instead of going to a patient, I went to the next one. (E4-29: L5; } \\
7-8)\end{array}$ \\
\hline $\begin{array}{l}\text { Errors in Transversal } \\
\text { Skills }\end{array}$ & $\begin{array}{l}\text { Performance independent of the } \\
\text { mentor's guidance }\end{array}$ & & $\begin{array}{l}\text { The reasoning being slowed down, the hand not sure. Mentor } \\
\text { must help. (E2-8: L106-107) } \\
\text { [The error was] not asking mentor for help on find the artery. } \\
\text { (E2-24: L73-74) }\end{array}$ \\
\hline \multirow[t]{2}{*}{ Errors in Care Planning } & $\begin{array}{l}\text { Definition of Nursing Diagnostics } \\
\text { according patient's needs in his } \\
\text { different dimensions }\end{array}$ & $\begin{array}{l}\text { Priorities } \\
\text { establishment }\end{array}$ & $\begin{array}{l}\text { [...] upon arriving at the ward I went directly to the nursing } \\
\text { room to obtain the necessary forms for admission. It was a great } \\
\text { failure for me not to have gone to my patient immediately [...] I } \\
\text { had failed because I did not set the right priority. (E2-12: L25-29; } \\
34-35 \text { ) }\end{array}$ \\
\hline & & $\begin{array}{l}\text { Lack of attendance } \\
\text { to patient }\end{array}$ & Ileft patient alone in the shower [...]. (E2-11: L19-20; 22-23) \\
\hline Errors in Care Evaluation & $\begin{array}{l}\text { Elaboration of records with useful } \\
\text { information continuity of care. }\end{array}$ & & $\begin{array}{l}\text { levaluated it and did recorded it and she [mentor] asked, "if } \\
\text { you have done it why didn't you recorded it?" What I observed } \\
\text { or performed I did not record [...] It took me a lot of time to hit } \\
\text { records. (E2-5: L168-170; 175; 179) }\end{array}$ \\
\hline
\end{tabular}

What are the nursing students' perceptions of their errors in clinical learning regarding circumstances surrounding it?

What was researched: contributions to the error; student's reaction toward committed error; actions after the error; error consequences to those involved; what could have prevented the error.

Students perceived themselves as the main contributor for the error (stress, fear of fail, lack of experience, lack of attention, shortage of theoretical knowledge; activities management). After, they point: mentors (problems in the relation, mainly because feeling afraid of them); Nursing School context (inadequate preparation); patients (their behavior); and colleagues (their presence).

Consequences to the persons involved were: to client (fall, injury, late medication intake, late meal). To staff nurse was a no conformity in the hospital auditory. To student: anxiety, fear of committing more errors, grade decreased, and failure.
Students revealed their perception of what could have prevented the error. Here, they attribute, in first place, factors to themselves: more attention, better communication with mentors, being calmer. Follow, factors of the Nursing School context: more time to activities, to know the patient, and in the ward. Again, students pointed to themselves the main factors to prevent errors, which is coherent with the perception of being the main contributor.

\section{To what extent do the students consider that the errors they committed contributed, hindered or impeded their learning and development?}

Second-year students considered more than 4th year that errors contributed to their learning. Errors as an impediment to learn and development was more mentioned by $4^{\text {th }}$ year participants. Students acknowledge that errors has contributed to their learning and development because they have recognized that there has been further 
development and awareness. Progress has been made by paying more attention, not repeating the occurrence, being more careful in preparing and administering medication, performing correctly, and planning activities differently. They became aware of: how to act in the future, their knowledge and what they need to know better.

The factors that fostered this learning were mostly related to student (reflection on action, transfer of knowledge and request for supervision). Also, related to the teaching/learning process, resurfacing the reflection on the action, either in group or with mentor. Mentor performance facilitated learning by correcting what was wrong, providing learning opportunity with errors, constructive critics, immediate feedback, demonstrating procedures, showing confidence in students, communicating calmly, explaining the consequences, and being open to doubts.

The error was obstruction for learning mainly for reasons related to other people, namely, mentors due to inadequate feedback, correction in the presence of other persons, stress, reprimand and no positive reinforcement. They also indicated factors related to themselves (anxiety) and with the teaching/learning context of the Nursing School: decreased grade; gap between theory and practice; lack of reflection. The error was understood as an impediment to learning because it impaired subsequent performance, therapeutic relationship and evaluation as well as it provoked subsequent decreased on of self-efficacy perception.

\section{DISCUSSION}

In discussion this research results it is important to have in mind that it's a study on student's perceptions. For nursing students the real experiences are associated with care and care associated with activities of the psychomotor domain ${ }^{(12)}$. Therefore, there is no surprise that participants pointed out, in first place, errors on the implementation phase where they are, mainly, near patient, at bedside.

Medication errors come in second position. Students fear mistakes and these in particular because they are aware of this issue on patient safety and quality of care $\mathrm{e}^{(13)}$.

Transversal skills are essential in nursing education. They are the foundation for all other competencies. In this category, students either committed mistakes because they were independent of mentor's guidance when they were not supposed to perform alone or, on the opposite, when they were already supposed to be independent but still needed mentor's help. The other subcategory is about being able to find strategies to overcome difficulties.

Care planning is the first step in nursing process. Many times (or much time in the first years) they don't perform this phase by themselves. This may be one of the reasons for perceiving less error in this category. The same applies to care evaluation when the mentor is present and discuss the outcomes with student.

Nursing students in clinical learning live real experiences and develop a sense of responsibility for their actions ${ }^{(14)}$ so, these finding are coherent with this and they understand that stress, fear of fail and other characteristics of their own lead to errors.

Regarding actions after the error, comparing actions that were performed with those students perceived that must be performed, there were coherence in reparation and attention to patient wellbeing. Students acted by repairing, evaluating patients well being, and reporting the error.
Student's reaction toward the error was frustration, anxiety; fear of failure, reflection-on-action, awareness of having committed an error, to assume the error to mentor, to patient and to nursing team, and reparation of the error. Frustration, anxiety, and fear of failure are common in nursing students when a mistake occurs ${ }^{(15)}$.

Other researches about nursing student errors reveals that these events have the potential to foster students learning and development ${ }^{(16)}$.

Learning fostering factors perceived by students are well documented in nursing education literature: reflection on action, feedback, constructive critics, being model ${ }^{(17)}$.

\section{Study limitations}

Main limitation of the qualitative part of this mixed methods research was not validation of analysis by $35 \%$ of participants. In spite of this, students declared they wanted their information to be included in the study.

\section{Advancements in knowledge}

The research revealed that although errors are not comfortable nor desirable in nursing care, they could be used in a constructive manner in nursing education and in nursing students learning and development. Medical errors were not the most present. Students ascribed to themselves reasons and prevention of the event.

\section{Contributions to the fields of nursing and health care}

Errors committed by nursing students during clinical learning can lead them to be secure clinical nurses compromised with patient's health and wellbeing. To this, organizations and persons involved in nursing education must be aware that errors occur and that they can be worked on and approached in a constructive manner with participation of all, from planning of clinical stay to evaluation. Student's mentors (staff nurses and faculty) must give immediate feedback, guide students learning process in an empathic and responsible way.

\section{FINAL CONSIDERATIONS}

Outcomes from qualitative methods informed and completed quantitative data on this research.

Therefore, Mixed Methods research is a very important path to study sensitive issues as errors committed in health care.

There were findings only possible by qualitative methods of collecting and analyzing data. Qualitative dimension of this research allowed entering in a problem that is not easy to present. In this study students acknowledged their errors and considered that these occurrences had potential to learn and development.

It was the qualitative part of this mixed methods research that allowed highlighting not only the errors committed by students but that they find themselves as the main contributing factors to these mistakes. In the same way, it was perceived that it was also on students the factors to avoid mistakes and to learn with them. The study achieved objectives because it analyzes errors committed by nursing students in clinical learning, factors 
associated with the events and how these were opportunities for learning and development.

This research implies some suggestions to nursing care, management, and education.

Two dimensions of the phenomenon must be the foundation: patient safety and students learning/development.

Since nursing students learn in real contexts with nurses who are role models, it is essential the awareness of this. So, from planning learning experiences to evaluation, institutions and organizations (universities, schools, hospitals, community services) must be together in a way to assure patients safety and students learning and development. A human climate of confidence and caring will help students. Staff nurses who are mentors and faculty should work together planning and developing learning and teaching strategies to help students learning. Mentors must be choose among nurses who have the skills to be an adequate role model. Pedagogical and educational training to guide nursing students should be provided. Guidelines to guide action when students make mistakes are essential to prevent patient, nurses, and students adverse consequences and improve learning and development of nursing students ${ }^{(3)}$.

Mixed methods research proved to be an effective way of study a sensible theme like this. It's important to understand both faculty and staff nurses perceptions on nursing students errors to find points of convergence with this study.

\section{REFERENCES}

1. Disch J, Barnsteiner J, Connor S, Brogren F. CE: Original research: Exploring How Nursing Schools Handle Student Errors and Near Misses. Am J Nurs [Internet]. 2017 [cited 2018 Dec 27];117(10):24-31. Available from: https://doi.org/10.1097/01.NAJ.0000525849.35536.74

2. Gorini A, Miglioretti M, Pravettoni G. A new perspective on blame culture: an experimental study. J Eval Clin Pract. 2012 [cited 2018 Dec 27]; 18(3):671-5. Available from: doi: https://doi.org/10.1111/j.1365-2753.2012.01831.x

3. Espada APSS. "O erro na aprendizagem clínica dos estudantes de enfermagem". Percepções de estudantes de enfermagem clínica sobre os erros cometidos e o papel que desempenham na aprendizagem e no desenvolvimento [Masters in the Internet]. Ponta Delgada (PT): Universidade dos Açores, Departamento de Ciências de Educação; 2013 [cited 2018 Dec 27]. 329 p. Available from: https://repositorio.uac. pt/bitstream/10400.3/3487/1/TeseDoutoramentoAnaPaulaSantosEspada2013.pdf

4. Institute of Medicine (US) Committee on Quality of Health Care in America; Kohn LT, Corrigan JM, Donaldson MS, editors. To Err is Human: Building a Safer Health System. Washington (DC): National Academies Press (US); 2000.

5. Drach-Zahavy A, Somech A, Admi H, Peterfreund I, Peker H, Priente O. (How) do we learn from errors? A prospective study of the link between the ward's learning practices and medication administration errors. Int J of Nurs Stud [Internet]. 2014 [cited 2018 Dec 27];51(3):448-57. Available from: https://doi.org /10.1016/j.ijnurstu.2013.06.010

6. Zieber MP, Williams B. The experience of nursing students who make mistakes in clinical. Int J Nurs Educ Scholarsh [Internet]. 2015 [cited 2018 Dec 27]; 12. pii:/j/ijnes.2015.12.issue-1/ijnes-2014-0070/ijnes-2014-0070.xml. Available from: https://doi.org/10.1515/ijnes-2014-0070

7. Sanz Gómez Al, Iriarte Ramos S, Gascón Catalán A. [Socio-demographic and work related issues in nursing care errors]. Enferm Glob [Internet]. 2016 [cited 2018 Jun 30];43:176-187. Available from: http://revistas.um.es/eglobal/article/view/214021/194681 Spanish.

8. Hewitt J, Tower M, Latimer S. An education intervention to improve nursing students' understanding of medication safety. Nurse Educ Pract [Internet]. 2015 [cited 2018 Dec 27];15(1):17-21. Available from: https://doi.org/10.1016/j.nepr.2014.11.001

9. Creswell JW, Clark VLP. Designing and Conducting Mixed Methods Research. 2 ed. Thousand Oaks: SAGE Publications; 2011.488 p.

10. Streubert HJ, Carpenter DR. Qualitative research in nursing: advancing the humanistic imperative. 5 ed. Philadelphia: Wolters Klumer, Lippincott Williams \& Wilkins; 2011. Chapter 3, Designing data generation and management strategies; 35-56.

11. Miles MB, Huberman AM. Qualitative Data Analysis: An Expanded Sourcebook. Thousand Oaks: Sage Publications; 1994.408 p.

12. Carter A G, Creedy DK, Sidebotham M. Evaluation of tools used to measure critical thinking development in nursing and midwifery undergraduate students: a systematic review. Nurse Educ Pract [Internet]. 2015 [cited 2018 Dec 27];35(7):864-74. Available from https://doi. org/10.1016/j.nedt.2015.02.023

13. Lima AB. Sentido de tornar-se responsável pelo cuidado nas vivências dos estudantes de enfermagem [Thesis in the Internet]. Salvador (BA): Universidade Federal da Bahia, Escola de Enfermagem; 2016 [cited 2018 Dec 27]. 212 p. Available from: http://repositorio.ufba.br/ri/handle/ri/22554

14. Latimer S, Hewitt J, Stanbrough R, McAndrew R. Reducing medication errors: Teaching strategies that increase nursing students' awareness of medication errors and their prevention. Nurse Educ Today [Internet]. 2017 [cited 2018 Dec 27];52:7-9. Available from: https://doi. org/10.1016/j.nedt.2017.02.004

15. Alzayyat A., Al-Gamal E. A review of the literature regarding stress among nursing students during their clinical education. Int Nurs Rev [Internet]. 2014 [cited 2018 Dec 27];61(3):406-15. Available from: https://doi.org/doi:10.1111/inr.12114

16. Tella S, Smith NJ, Partanen $P$, Jamookeeah D, Lamidi ML, Turunen H. Learning to ensure patient safety in clinical settings: comparing Finnish and British nursing students' perceptions. J Clin Nurs [Internet]. 2015 [cited 2018 Dec 27];24(19-20):2954-64. Available from: https://doi. org/10.1111/jocn.12914

17. Yardimci F, Bektas M, Özkütük N, Muslu K, Gerceker GO, Basbakkal Z. A study of the relationship between the study process, motivation resources, and motivation problems of nursing students in different educational system. Nurse Educ Today [Internet]. 2017 [cited 2018 Dec 27];48:13-8. Available from: https://doi.org/10.1016/j.nedt.2016.09.017 